\title{
The Inheritance of Chinese Traditional Music in College Music Education Chen Wei ${ }^{1}$, \\ ${ }^{1}$ College of Humanities \& Sciences of Northeast Normal University, Changchun City, Jilin Province, China, 130000
}

\section{Keywords: College music education; Chinese traditional music; Inheritance measure}

\begin{abstract}
With the globalization of economy, China has closer relations with other countries. Music education in our country also begin to show a diversified musical art form and promote the development of music education in our country. But it also causes the marginalization of traditional music in college music teaching. Some music teachers ignore the traditional music directly, which is not conducive to the succession and development of traditional music in our country. In view of this, this article elaborates the measures and methods of inheriting Chinese traditional music in college music education.

College music education shoulders the mission of training high-quality music talents and inheriting Chinese traditional music. Therefore, in practical teaching, effective measures should be taken to integrate Chinese traditional music elements, stimulate students' interest in traditional music, and then take the initiative to devote themselves to the great tradition of music transmission career. At present, due to the impact and influence of diversified western musical forms, gradual emergence of marginalization of traditional music in music education at colleges and universities, therefore, measures should be taken to solve this problem.
\end{abstract}

\section{The Necessity of Traditional Musical Heritage}

The inheritance of Chinese traditional music in music education at colleges plays a role in many aspects, such as the national sentiment contained in it, including the culture and national traditional skills of the nation, etc. This section mainly analyzes the contents of these three aspects and How to do a good job for the later exposition bedding.

\section{Contain National Emotion}

It is particularly important for our nation having many nationalities to do a good job of national unity and emotional exchanges. Traditional music itself has strong national characteristics. Many times it records the development and history of its people. For example, the famous "Yellow River Chorus" is a blend of Chinese national sentiments. Inheriting traditional music and maintaining national emotions will help raise the sense of national cohesion and honor.

\section{Stand for National Culture}

There are many forms of music in traditional Chinese culture, including folk songs, traditional operas, song and dance, etc. There are also some small categories below each major category, for example, folk songs are divided into songs and minor notes. However, no matter what form they are, they all have rich ethnic characteristics and directly express their own ethnic cultures and customs, such as the highly-praised "Qinghai-Tibet Plateau", which show different cultural backgrounds.

\section{Carry the Traditional Skills}

The most prominent feature of traditional music is its distinctive national musical instruments. The production of national musical instruments is a traditional memory in itself, with artistic features and geographical colors, and inheriting traditional music. There are many kinds of national musical instruments and many arts and crafts, among which are Hulusi, erhu and chimes, which have rich characteristics.

\section{Chinese Traditional Music Heritage Content Analysis}

It is not indiscriminate to pass on traditional Chinese music in college musical education. Instead, inheriting the excellent traditional music that has been precipitated by the washing of history. Inheriting these traditional music helps to establish the correct musical values and musical 
aesthetics. Traditional music heritage should do the following work.

Firstly, accept the theoretical education of Chinese traditional music. At the beginning of last century, our country began to contact western musical theory knowledge education, resulting in the vast majority of people starting to study Western music education methods, lack of interest in the study of their traditional music theory. However, under these circumstances, a large number of people are involved in the field and gradually turn around the concept of people in the country, such as Cai Yuanpei and Xiao Youmei. In recent years, the development of traditional Chinese music has drawn much attention from all quarters. In particular, following the success of the four major integrated traditional music compilations, the promotion of traditional music has been vigorously promoted and a large number of theoretical achievements have emerged. After the introduction of these theoretical achievements, college music education further improves and optimizes the teaching of traditional music theory.

Secondly, summarize and analyze the law of music development. In order to promote the construction of traditional Chinese music, relevant personnel are required to constantly study and summarize the theories and laws governing the development of various types of music, to fully study the culture inherent in traditional music, to clarify the characteristics of traditional music culture, to insist on traditional music as the guide and to inherit the fine tradition. Through analyzing and summarizing the law of development of all kinds of music, we can use these rules to extract the law and trend of the development of traditional music and to promote inheritance.

Finally, inherit the correct musical values. There are many traditional music contents in China. Every ethnic group's music has its own value. The responsibility of future generations is to inherit these excellent traditional music values. The basis of this work is to have a sense of music identity. Music heritage should hold an open attitude, not because it is the nation's indiscriminate acceptance, not the nation is the conflict, the inheritance of ethnic music must also respect other peoples. Avoid extreme nationalism or "worship foreign" psychology, these are not conducive to the tradition and development of traditional music. Establishing the conception of the values and aesthetic values of music is the necessary condition and basis for the realization of the traditional music.

\section{Measures of College Music Education Heritage of Chinese Traditional Music}

College music education undertakes the important task of cultivating high-quality musical talents, and also shoulders the responsibility of inheriting Chinese traditional music. In order to cultivate high-quality music talents, we can infiltrate the Chinese traditional music culture in music teaching. By learning traditional music, we can learn more about traditional music and become more interested in it. We can start from the following aspects to achieve the traditional Chinese music heritage.

\section{Take Measures to Effectively Stimulate Interest in Learning}

In the actual music game design content, it should be sure to meet the psychological development of college students, students should be able to understand things as a material for teaching, easy to understand song content to enable students to better understand the concept of teacher teaching, so teachers choose common things in life to teaching, far better than some abstract expression of the song better.

The concept of the new curriculum reform is to use college students as the main body of teaching, to change the previous "one-word-one" teaching method, and to require teachers to give back the initiative of the classroom to the students. The same applies to music and mental health education classes. Teaching, teachers should use a variety of teaching methods to guide college students, so that they take the initiative to participate in the study of music, from their own practical experience in the perception of musical charm, to create a good teaching atmosphere, to help students develop imagination and thinking Space development.

At the same time, the harmonious relationship between teachers and students can promote the exchange of emotions, while the emotional interaction is the key to mental health education. The use of music teaching process and college students psychic interaction, virtually mental health education for college students. Therefore, in order to narrow the distance with college students, 
teachers should first turn themselves into a student. In music teaching, teachers should make appropriate changes in their roles, regard themselves as college students, and use their true feelings to impress them. They all enjoy singing together, Dance, build a good teaching environment at the same time, to create a safe, happy, harmonious and free emotional experience for college students.

\section{Curriculum Setting, Flexibly According to the Situation}

The music classroom in colleges is the main area of music education. It is also the main way of inheriting traditional music. Therefore, it is necessary to organically integrate the traditional music in the setting of school curriculums. This is not to say that we completely abandon the modern western music education system when we carry out music education for students but instead of advocating schools to guide students to fully realize the importance of traditional music education while guiding their students in music education. On the basis of traditional music study, we should not blindly follow the rational evaluation and study of western music art system.

For example, when teaching music to college students, bilingual teaching can be used to organically integrate our traditional music education with western music education. We should try our best to maintain the harmony between the two in setting up and arranging music lessons for students. When they encounter the same nature of teaching content, teachers can also lead students to carry out the activities of Chinese and Western music teaching, which not only avoid the teaching method of separating the two sides, but also deepen the connection between the two. During the music course setup, teachers should give equal consideration to Chinese traditional music and western music at the same time. It not only enriches the content of music teaching in colleges and universities, but also enables the two to complement each other with each other's strengths and rapidly improve their musical level and accomplishment.

\section{Innovate Methods, Introduce Information Technology}

To enhance students' learning and inheritance of traditional Chinese music, apart from making reasonable adjustments and improvements in the curriculum of colleges and universities, we must also make proper reforms and innovations in educational methods. In recent years, with the rapid popularization of computer technology and Internet technology, modern teaching methods are commonly introduced in many colleges and universities. According to the survey, at present, most students like to use digital media to acquire the latest music knowledge.

The digital media here is different from ordinary newspapers and magazines, television broadcasting, etc. It mainly refers to the computer, digital television, digital communication technology, computer technology, etc., in order to provide a wide range of information services to the general public. Moreover, this teaching method also provides an opportunity for traditional music education and inheritance in colleges. For example, schools can divide traditional music lessons into traditional music theory teaching, ethnic musical instrument appreciation and appreciation of national vocal music, and then employ well-known music teachers and musicians inside and outside the school to give lectures on the spot and then record them into video, using digital media technology to publish it in online classrooms, to facilitate more students to conduct online learning and after-school consolidation, distance education, teaching methods and students to obtain more knowledge of music methods more flexible. Moreover, this teaching method is not only flexible, but also more in line with the current situation of education development and enhance the diversity and interest of music education. In addition, with the rapid interest of communication platforms such as QQ, Microblog and WeChat, and widely enjoyed by teachers and students, colleges can use these platforms to disseminate traditional music knowledge and skills, educate and guide students to pay attention to traditional music, Conduct self-learning and inheritance.

\section{Organize Activities, Give Full Play to the Role of Practice}

The purpose of music education in colleges is to teach students not only master the rich basic knowledge of music and solid musical performance skills, but also popularize Chinese traditional music and deepen students' love and understanding of traditional music, so as to guide them to consciously take on traditional Chinese culture Music heritage and publicity. Therefore, colleges should try their best to carry out a number of rich and varied music practices to help students consolidate and internalize their knowledge of music in practice, and rapidly improve their own 
comprehensive skills and musical performance skills and appreciation levels.

For example, schools should take various forms of education measures to help students realize the importance of traditional music learning and inheritance. According to the actual conditions of their schools and students' preference, some famous musicology artists from home and abroad are invited to go to school for music performance and lectures, make the students know more about traditional music knowledge, appreciate the charm and shock of traditional music in the process of appreciation, enhance the students 'determination and confidence in learning traditional music; at the same time, expand students' visual field of music and culture; In addition, the school should provide students with a variety of practical platforms and opportunities for traditional music, encourage and guide students to create music associations and music thematic conferences on traditional music, etc., and help students to understand traditional music and perceive the unique beauty of traditional music in many aspects .

In addition to the basic classroom teaching in college music teaching, there are various extra-curricular cultural activities, and these literary activities also play an important role in the inheritance of Chinese traditional musical culture. It can hold traditional themed music activities, both practice the ability of students, but also to feel the beauty, stimulate interest in the performance of the traditional music, hoping to further contact with traditional music, but also produce a new understanding of traditional music, to achieve an effective heritage.

China's traditional music materials come from the private sector, so in order to better understand the traditional music, schools should organize students out of school, into the country, more real contact with folk music. By participating in folk music activities, we can further experience the traditional folk music in our own nation and deepen the recognition of our national music. Teachers also focus on encouraging students to trace the source, in-depth practice, through hard work to get the most authentic and reliable information. On the basis of a solid traditional culture, the traditional music culture is studied based on the data obtained through practice. The research results are fused with the research results left by his predecessors to create a new traditional musical culture with characteristics.

\section{Conclusion}

In short, although the traditional Chinese musical heritage faces challenges, we must believe that the music handed down after the test of time has its own bright spot and also has its own merits in modern society. At the same time, most of the traditional music comes from the folk. The traditional music can not be divorced from the masses when it is handed down to the public. It is necessary to go deep into the folk and understand the production and inheritance of traditional music. It also organically permeates these contents during the teaching so that the success of traditional music can be successfully realized. Hope that through this article, it could provide similar experience for reference.

\section{References}

[1] Xiao Xiong. Research on Minority Traditional Music Culture and College Music Education Reform [J]. High Voice of the Yellow River. 2017 (01): 92.

[2] Cui Xuerong. The Construction and Expression of the Objectives of Chinese Traditional Music and Culture Education [J]. Journal of Music. 2011 (02): 89.

[3] Ji Zhidan. Discussion on college music education and cultural market docking strategy [J]. Popular Song .2015 (11): 34.

[4] Huang Suyi. The development of music education in colleges and universities [J]. Arts. 2016 (10): 45-47.

[5] Zhang Mei. Project-driven teaching in the implementation of music education in colleges and universities [J]. Knowledge Economy .2017 (16): 81.

[6] Liao Dan. Analysis of the Intangible Cultural Heritage Protection of Music from the Three Characteristics of Traditional Music [J]. Chinese Music. 2013 (01): 23. 
[7] Guo Xiaoli, Wang Yaohua. To Get Active Source Water - Discussion on the Inheritance and Innovation of Traditional Chinese Music in Music Creation [J] .People's Music. 2012 (01): 92-94.

[8] Cui Xuerong. Optimistic Strategies for Teaching Chinese Traditional Musical Culture from the Perspective of Aesthetics [J]. Hong Huang (Journal of Wuhan Conservatory of Music, China2012 (02): 112)

[9] Hu Shihong. The Heritage and Development of Traditional Music in College Music Education under Multicultural Background [J]. Yalu Jiang (Second Half Edition). 2014 (09): 121.

[10]Zhang Mei.College music education on the innovative thinking of college students and suggestions [J]. Modern Commerce and Industry. 2017 (21): 22. 